DOROTA GUTTFELD

Uniwersytet im. Mikołaja Kopernika w Toruniu

E-mail: gutt@umk.pl

\title{
FANDOM I MARKOWE WSZECHŚWIATY: EWOLUCJA CZYNNIKÓW WPŁYWAJĄCYCH NA POLSKIE PRZEKŁADY ANGLOJĘZYCZNEJ FANTASTYKI
}

\begin{abstract}
Fans and Franchises: The Evolution of Factors Influencing Polish Translations of Speculative Fiction

Polish fans of science fiction, fantasy and horror (here referred to jointly as speculative fiction) emerged as a notable target audience for translations in the 1980s. Widely available translations from English in these genres started to appear in the 1990s, and were instrumental in establishing their popularity in Poland. At that formative stage, the renderings available assumed what polysystems theory would call a primary or central position. After the genre-forming period, however, translations have become subject to a number of new pressures: the expectations of a fan audience with an increasing competence in English; the growing accessibility of English-language originals; and the accumulating body of previous translations, including audiovisual and digital texts in major series and franchises. Due to these factors, translations of speculative fiction have been undergoing a demotion from their genre-making role, assuming the default, secondary or peripheral role in the polysystem. Since this role is played in a polysystem they once helped shape, the conservatism of peripheral translations involves their compliance with previous translation standards and canonized renderings, and is reinforced by the influence of digital media, which typically offer vulnerable translations (i.e. translations easily compared to or present alongside original versions). This goes hand in hand with the emergence of speculative fiction as a shared idiom of popular culture, with its interest in lucrative media franchises and shared universes. As written texts and their translations now constitute a less prominent section of the spectrum of
\end{abstract}


speculative fiction available to fans, ties to other texts, notably digital and audiovisual ones, may be prioritized over other qualities of translation. The evolution of translations is accompanied by that of the genres' readership: as an audience, Polish fans of speculative fiction in the $21^{\text {st }}$ century seem to be characterized by their interest primarily in the world depicted by the authors and its consistency.

Keywords: science fiction, fantasy, literary translation, genre literature

Słowa kluczowe: science fiction, fantasy, przekład literacki, literatura gatunków

W rozwoju gatunków science fiction i fantasy w Polsce można wyróżnić trzy okresy istotne z punktu widzenia historii ich przekładu z języka angielskiego: okres formacyjny, przypadający na lata 1980-1989, kiedy nieliczne przekłady literackiej fantastyki z języka angielskiego odgrywały rolę dominującą i gatunkotwórczą, funkcjonując w dwóch obiegach: profesjonalnym i fanowskim; okres gatunkowy od 1989 do późnych lat 90., kiedy w ramach nadrabiania zaległości nastąpiła profesjonalizacja tłumaczy-fanów i gwałtowny przyrost liczby tłumaczeń oraz rozrost fandomu ${ }^{1}$; i okres popkulturowy, od przełomu XX i XXI wieku, kiedy fantastyka weszła do głównego nurtu kultury popularnej, a jej literackie wcielenie stało się tylko jednym z aspektów interesujących umasowiony fandom. Fakt, że główną cezurą jest rok związany z przełomem politycznym, wynika z tego, że pociągnął on za sobą przemiany ekonomiczne, które wpłynęły na rynek wydawniczy, socjologię i kulturę przekładu. Trzy główne czynniki definiujące sytuację tłumaczy to: pozycja przekładów w ramach systemu polskiej fantastyki, pojawianie się dodatkowych typów presji na tłumaczenia w okresie gatunkowym i popkulturowym oraz zmiany tożsamości i oczekiwań fanów.

Na potrzeby niniejszego artykułu „fantastyka” będzie równoznaczna z gatunkami science fiction, fantasy i horrorem, a „fan” będzie oznaczać odbiorcę emocjonalnie zaangażowanego w recepcję tekstu, łączącego jego odbiór (często wielokrotny) z innymi formami aktywności (np. kolekcjonerstwem, tworzeniem własnych tekstów) i wchodzącego w kontakt z innymi fanami w ramach grup towarzyskich lub zinstytucjonalizowanych, realnych bądź wirtualnych. Należy przy tym pamiętać, że fandomu, nie można

${ }^{1}$ Fandom - aktywna, zorganizowana społeczność fanowska. 
zrównywać z ogółem odbiorców fantastyki i niekoniecznie stanowi on główną publiczność docelową przekładów. Jednocześnie to tę najbardziej uspołecznioną grupę najłatwiej zbadać i zdefiniować, a jej aktywność sprawia, że może stanowić ważny punkt odniesienia i dla pozostałych odbiorców, i dla rynku wydawniczego. Wypowiedzi na temat współczesnych fanów fantastyki będę opierać na badaniu „Fantastyczni 2012” (Guttfeld, Jankowiak, Krawczyk 2013).

\section{Okres formacyjny}

Polska społeczność fanów przyjęła zorganizowaną formę i zaczęła funkcjonować jako zauważalna grupa odbiorców w latach 80 . XX wieku wokół pierwszych periodyków, klubów i imprez fanowskich. W tym okresie tłumaczenia anglojęzycznej fantastyki literackiej były nieliczne i starannie dobierane, co przekładało się na ich duży ciężar gatunkowy (również rozumiany jako wpływ na pojmowanie gatunków literackich). W rozumieniu teorii polisystemowej Itamara Even-Zohara (2005) oznaczało to centralną pozycję tłumaczy i przekładów z angielskiego, który był (i pozostaje) głównym językiem gatunku.

Staranny dobór tekstów do tłumaczenia wynikał oczywiście z kwestii ekonomicznych, modelu organizacji wydawnictw i ówczesnej kultury wydawniczej. Dobrym przykładem realiów może być casus serii wydawniczej „Stanisław Lem przedstawia”, której Lem był twórcą i patronem. Z jednej strony seria ukazywała się w prestiżowym Wydawnictwie Literackim, w nieosiągalnych dziś nakładach, bez presji wyników rynkowych. Przekładało się to na priorytetowe traktowanie wartości literackiej utworów, podczas gdy ich przynależność gatunkowa i relacje z innymi utworami fantastycznymi mogły być mniej istotne. Z pierwszych sześciu planowanych utworów pięć miało być tłumaczeniami, w tym cztery z angielskiego. Połączenie wydawnictwa literackiego, osoby patrona (za którym świadczyły już wówczas jego największe dzieła) i doboru tłumaczy (m.in. Stanisława Barańczaka) miało szansę istotnie wpłynąć na recepcję literatury fantastycznej w Polsce. $\mathrm{Z}$ drugiej strony seria była zakładnikiem realiów PRL-u: problemów zaopatrzeniowych i biurokratycznych, cenzury i ideologicznych nacisków, co ostatecznie spowodowało rezygnację zjej wydawania już po czterech pierwszych tomach. Klimat, w którym patron serii musiał uciekać się do technik z pogranicza emocjonalnego i ideologicznego szantażu, by przewalczyć 
publikację, najlepiej oddaje list Lema do Andrzeja Kurza, ówczesnego dyrektora Wydawnictwa, datowany na 19 grudnia 1976 roku:

\section{Szanowny Panie Dyrektorze}

Przed naszą planowaną naradą na szczycie, dotyczyć mającą przyszłości serii „S. Lem poleca”, pozwalam sobie niniejszym, podług obyczajów, właściwych wielkiej polityce, przedłożyć Pana uwadze poniższe memorandum. Seria znajduje się w kłopotach, ponieważ aktualnie cztery jej pozycje nie mogą wyjść. Dwie dlatego, ponieważ każdy z thumaczy stał się persona non grata dla naszych władz. Trzecia książka, gdyż właściciel praw chce całego honorarium w dewizach. I wreszcie w czwartym wypadku sam autor podobno - ale o tym wiem tylko ze słuchów - nie życzy sobie wydania swego tekstu w kraju rządzonym przez partię komunistyczną. Co się tyczy pierwszych dwóch książek, pominę wysokie względy natury społeczno-etycznej, które przemawiają za publikacją dzieł, przekładanych przez osoby, co się znalazły w politycznej niełasce, ponieważ taka prohibicyjna polityka w sposób oczywisty urąga wszystkiemu, co się w naszym ustroju głosi o opiece nad kulturą. Nie wchodząc tedy w merytoryczny spór co do zasad takiej prohibicji, chciałbym zauważyć jedynie, że kiedy wybrałem rzeczone tytuły do serii, ten mój wybór był ogłoszony publicznie. W szczególności, pierwszy, w wywiadzie, udzielonym warszawskiemu korespondentowi „Izwiestii”, a drugi wybór - osobiście mi znanej autorce odnośnego tytułu, pani Urszuli LeGuin. Jest więc dla mnie niemożliwością na dłuższą metę nie zakomunikować zainteresowanej stronie, dlaczego książka ukazać się w Wydawnictwie Literackim nie może. Nie będzie to zapewne miało światem wstrząsających reperkusji, ale zarazem nie będzie to wiadomość dla nas osobliwie pochlebna. Przypadek trzeci, autora żądającego honorarium w wymienialnych dewizach, nadaje się, mam nadzieję, do dalszych negocjacji. (...) Obawiam się, że niewydanie nazwanych, a do druku przygotowanych książek, zada fatalny cios serii, która się już z niego nie podniesie. I wtedy, zapewne, nie powstanie od takiego zaniechania dziura w niebie, ale będzie to symptom, nader niekorzystnie świadczący o naszej edytorskiej polityce (Lem 1976).

Tłumacze, o których chodzi, to tłumaczka Pikniku na skraju drogi Strugackich, Irena Lewandowska, która współpracowała z KOR i w styczniu tego roku podpisała „Memoriał 101” (w stanie wojennym miała zostać na krótko internowana za działalność w „Solidarności” Regionu Mazowsze) (Głębicka 2017; Orliński 2007: 210), oraz Barańczak, którego przekład Czarnoksiężnika $z$ archipelagu LeGuin miał być piątym tomem serii (ostatecznie ukazał się już w innej serii WL, choć również z posłowiem Lema). Kwestia płatności w dolarach za przekład Ubika, którego dokonał Michał Ronikier, 
doprowadziła do słynnego spięcia między Lemem a P.K. Dickiem, który uznał, że Lem usiłuje go oszukać, a być może jest w istocie komórką KGB.

Ponieważ oficjalne wydania nie mogły zaspokoić zapotrzebowania, które tymczasem rodziło się wśród czytelników fantastyki gromadzących się w latach 80. wokół klubów i ich czasopism, a z czasem wokół pisma „Fantastyka”, pojawił się drugi typ przekładów, publikowanych w wydawnictwach klubowych przez i dla fanów. W przypadku języka angielskiego, który był głównym językiem źródłowym, tłumacze-fani zazwyczaj nie mieli wykształcenia filologicznego; byli to często studenci lub absolwenci kierunków ścisłych z doświadczeniem w czytaniu tekstów naukowo-technicznych w tym języku albo osoby, które ze względów rodzinnych lub zawodowych miały kontakty z zagranicą i zostawały „oddelegowane” do zadań tłumaczy. W takich okolicznościach można się spodziewać przeważnie przekładów wiernych w sensie słownikowym, w których thumacze metodą prób i błędów dopiero dochodzą do indywidualnych strategii radzenia sobie z problemami. Jakość literacka tekstów nie była zresztą najważniejsza, tłumaczenia nie spotykały się też raczej z krytyką - istotny był fakt, że w ogóle istniały, a przekłady należały do gatunku, który sam w sobie cieszył się zainteresowaniem czytelników. Tłumacze i redaktorzy wydawnictw fanowskich mimo braku doświadczenia dysponowali dużą autonomią, czasami bezpośrednio kontaktując się z autorami przy okazji konwentów czy wyjazdów zagranicznych, i pozyskując teksty dzięki dobrej woli w stosunku do fanów zza żelaznej kurtyny; tak więc również na tym polu przekłady miały moc kształtowania gatunku.

\section{Okres gatunkowy}

Przekłady fanowskie, znane jako „klubówki”, pojawiły się znów w obiegu po eksplozji wydawniczej, jaka nastąpiła na początku lat 90., po przełomie 1989 roku, kiedy wydawcy (niekiedy przedsiębiorczy fani) zaczęli nadrabiać zaległości w podaży horroru, science fiction i fantasy, głównie anglojęzycznych, niekiedy korzystając właśnie z uprzednich przekładów klubowych. Niektórzy ich autorzy orientowali się, że są w ten sposób w stanie zarobić na życie i zostawali zawodowymi tłumaczami. Przekłady odgrywały absolutnie dominującą rolę w rozwoju gatunku i jego postrzegania w Polsce, jednak wobec masy tekstów i tempa ich redakcji zarówno teksty źródłowe, jak i tłumaczenia miały oczywiście bardzo różną wartość, co przyczyniało 
się do postrzeganej przez fanów i omawianej przez krytyków „gettoizacji” utworów fantastycznych, które, pojawiając się już raczej w wydawnictwach popularnych, zwracały się coraz bardziej do czytelników przekonanych już do tej literatury i podkreślały swoją przynależność do danego podgatunku czy serii. O ile perypetie Lema w Wydawnictwie Literackim mogły być charakterystyczne dla poprzedniej epoki, w „okresie gatunkowym” tekstem sygnalizującym pewną zmianę jest pierwszy odcinek cyklu felietonów „Tygrys szablastodzioby” Pauliny Braiter z marca 1992 roku. W czasopiśmie „Fenix” tłumaczka zapowiada kronikę „tego, co przytrafiło się w ostatnich latach sztuce translatorskiej, edytorskiej i całemu w ogóle rynkowi książki. Czyli totalnej zapaści”, i przypomina, jak „w dawnych dobrych czasach «wydawnictw klubowych» został kompletnie zarżnięty Wyndham, jak «Zakluczone królestwo» doprowadzało do szału wielbicieli Ziemiomorza (...). Ale co było robić” (mowa tu o klubowym tłumaczeniu „Grobowców Atuanu" LeGuin z 1986, dalszej części cyklu, który rozpoczął przekład Barańczaka w 1983 r.). O ile jednak niedostatki „klubówek” trudno było krytykować, teraz czas niskich standardów powinien się skończyć, zanim poczyni nieodwracalne szkody recepcji ,niektórych już nie autorów czy wydawnictw, lecz wręcz gatunków literackich (...) fantastyka w jakości tłumaczeń i redakcji tekstów idzie łeb w łeb z horrorem i sensacją, nieco tylko wyprzedzając romanse”, podczas gdy jeszcze niedawno „fakt pojawienia się czegoś w książce wystarczył, by traktować to jako wzorzec poprawności”. Felieton wskazuje też na żenujący poziom literacki i intelektualny wielu wybieranych do publikacji utworów, ale przede wszystkim przekładów, przez które „człowiek niby czyta słynną powieść fantastyczną, kamień milowy w rozwoju światowej SF - i nic” (Braiter 1992).

Rzecz jasna w tym samym czasie tłumacze debiutujący w klubówkach i ich młodsi koledzy zdobywali też doświadczenie i dojrzewali do własnej filozofii przekładu, niekoniecznie już nakierowanej na prosto rozumianą wierność oryginałowi. Przekład drugiej części cyklu o Ziemiomorzu już w 1990 roku pojawił się w znacznie lepszej wersji Piotra W. Cholewy, późniejszego prezesa Europejskiego Stowarzyszenia Science Fiction i Związku Stowarzyszeń Fandom Polski. Sama Paulina Braiter, obecnie w czołówce wśród tłumaczy fantastyki o największym dorobku (Fantasta.pl 2018), miała poprawić przekład trzeciej części tego samego cyklu, Najdalszy brzeg, w roku 1996. Warto jednak zauważyć, że o ile Barańczak, przekładając część pierwszą cyklu, cieszył się dużą swobodą, jeżeli chodzi o styl przekładu, podejście do terminologii, nazw własnych, a nawet przekładu tytułu (którym 
przesunął utwór w stronę literatury głównonurtowej, unikając neologizmu fikcyjnej nazwy i lekceważąc istotne w powieści rozróżnienie na czarodziei i czarowników ${ }^{2}$ ), o tyle dalsze przekłady musiały już zadbać o spójność z poprzednimi tekstami i całościową wizją świata przedstawionego - a kiedy tego nie czyniły z należytą uwagą, wystawiały się na krytykę fanów serii. Tego typu kwestie zaczęły wysuwać się na pierwszy plan zwłaszcza w kolejnym okresie, tym razem rozpoczynającym się bez wyraźnej cezury, pod koniec lat 90. i trwającym na przełomie wieków. Przed rokiem 1989 tłumaczy wywodzących się z fandomu zazwyczaj ograniczał brak doświadczenia, zawężający repertuar dostępnych im opcji przekładu, a teraz okno możliwości zaczęło się zamykać ze względu na rosnącą świadomość rynkowego potencjału światów fantastycznych. By posłużyć się metaforą: być może „archipelag” bardziej podobał się tłumaczowi i brzmiał bardziej przystępnie dla czytelników literatury głównego nurtu, ale marką rozpoznawalną dla fanów z ,getta”, identyfikującą tekst jako fantastykę i element znanego już cyklu, mogło zostać raczej ,Ziemiomorze”.

\section{Okres popkulturowy}

Nowe czynniki, które zaczęły wywierać presję na tłumaczy, wiązały się z przyrostem liczby istniejących tłumaczeń i utrwalającą się percepcją fantastyki jako części popkultury, której ważną cechą jest serwowanie odbiorcy sprawdzonych produktów. Nowe przekłady musiały pasować do tych już istniejących w ramach danej serii, cyklu, czy „franczyzy”: złożonego z wielu, tekstów, mediów i produktów wszechświata, którego zaledwie jedną z odsłon, i to często coraz mniej procentowo znaczącą, stanowiły teksty literackie. W latach 90. fantastyczne teksty nieliterackie - filmy, gry fabularne i komputerowe - pojawiały się początkowo w wersjach ory-

${ }^{2}$ W oryginale istnieje rozróżnienie na ,wizards” (w pełni wykwalifikowanych magów, posłusznych przede wszystkim filozofii swojej sztuki) i „sorcerers” (magów, którzy nie przeszli pełnego szkolenia i świadczą bardziej przyziemne usługi). Tych pierwszych przekłada Barańczak jako „czarodziejów”, tych drugich jako „czarowników”, jednak w tytule jako odpowiednik „wizard” pojawia się jeszcze inny termin, „czarnoksiężnik”, niestosujący się do tytułowego bohatera, zazwyczaj używany jako określenie użytkownika czarnej magii (jak np. przez Skibniewską w przekładzie Tolkienowskiego „necromancer”). Najwyraźniej niekonsekwencja w użyciu terminologii specyficznej dla wyobrażonego świata okazała się mniej ważna niż brzmienie tytułu. 
ginalnych, a następnie w przekładach, które nie ukrywały przed odbiorcą tekstu oryginalnego. Tego typu ,przekład wrażliwy”3 premiuje uniwersalne, jednolite strategie tłumaczeniowe, na przykład w postaci zapożyczeń i tłumaczenia stosunkowo dosłownego, „odwracalnego” dla fana, który może znać oryginał, a zwłaszcza konsekwentne i jednolite podejście do nazewnictwa i terminologii. Te ostatnie w przypadku najbardziej dochodowych uniwersów mogą wręcz być opatrzone znakiem towarowym. Pod koniec lat 90. gry, stanowiące coraz ważniejsze medium, zaczęły również być masowo dostępne dla polskich odbiorców w wersjach całkowicie spolszczonych, i to te spolszczenia wprowadzały niekiedy terminologię obowiązującą tłumaczy literackich (1999 rok to pierwsza wysokobudżetowa lokalizacja gry komputerowej Baldur's Gate przez CD Projekt, w 2000 powstało wydawnictwo Copernicus specjalizujące się w powieściach ze świata gier fabularnych i bitewnych Warhammer i Warhammer 40.000).

Jednocześnie odbiorcy polscy, o rosnącej znajomości angielskiego, jako konsumenci zróżnicowanych mediów, z dostępem do oryginałów, mogli dyktować wydawcom i tłumaczom wymagania. Tłumacze literatury fantastycznej przestali odgrywać tak istotną rolę w kształtowaniu fantastyki, choćby dlatego, że znaczna część twórczości fantastycznej przeniosła się poza literaturę. W tekstach nieliterackich, nawet jeżeli korzenie samych tłumaczy pozostawały podobne, sposób przekładu dyktowały już w większym stopniu czynniki związane ze specyfiką medium i utrzymaniem tożsamości marki. Co za tym idzie, przekłady literackie wpasowujące się w system już istniejących tekstów kultury musiały się stać bardziej konserwatywne i mniej zindywidualizowane, ponieważ nie dobiera się już strategii przekładu organicznie do konkretnego tekstu; nie tekst bywa tłumaczony, ale markowy wszechświat, o którego przyszłości trzeba myśleć, konsultując się z publicznością, glosariuszami, albo wręcz przechodząc swoistą fazę QA, znaną z tłumaczeń użytkowych, jak w przypadku powieści ze świata „Gwiezdnych Wojen”.

3 Vulnerable translation to przekład, który ze względu na współwystępowanie z oryginałem narażony jest na krytykę ze strony odbiorców znających w jakimś stopniu język źródłowy. W stosunku do napisów filmowych termin stosują Jorge Diaz Cintas i Aline Remael (2007); wcześniej Dìaz Cintas wprowadza go w publikacji hiszpańskojęzycznej (2003). 


\section{Oczekiwania miłośników fantastyki}

Stosunek fanów fantastyki do gatunku i do problemów przekładu został opisany na grupie ponad tysiąca osób: uczestników konwentu Pyrkon 2012 i respondentów internetowych w ramach badania „Fantastyczni 2012” (Guttfeld, Jankowiak, Krawczyk 2013). Wśród kwestii istotnych dla thumaczy $\mathrm{w}$ raporcie po badaniu pojawiło się postrzeganie fantastyki przez fanów. Główną zaletą fantastyki okazało się, według respondentów, przedstawianie innych światów, odmiennych od rzeczywistości, w sposób pozwalający na przeniesienie się do nich wyobraźnią. W gruncie rzeczy wydaje się, że fani oczekują od fantastyki funkcji mimetycznej, której nie należy mylić z realizmem; fakt, że jest to mimesis nieistniejącego świata, paradoksalnie czyni ją jeszcze ważniejszą, jeżeli istotnie ma być możliwa immersja. Spójność tekstu (w tym przekładu) w ramach konwencji gatunkowych i jego potencjał immersyjny sytuowałyby się zatem pośród głównych oczekiwań odbiorców. Można spekulować, że skoro elementy językowe, takie jak neologizmy czy nazwy własne, odgrywają istotną rolę w kreacji świata przedstawionego, to fan może zaakceptować terminy dziwne, niezrozumiałe czy obcojęzyczne, ale nie niekonsekwentne czy nielogicznie stosowane, bo to zdradziłoby ich czysto literacką, fikcyjną naturę.

Fantastyka była głównym składnikiem „diety literackiej” respondentów; zależnie od podgrupy, stanowiła 75\% i 69\% wszelkiej czytanej literatury (odpowiednio: wśród uczestników konwentu i respondentów internetowych); ulubione książki czytano zazwyczaj wielokrotnie. Ponad połowa respondentów zadeklarowała też czytanie fantastyki w języku angielskim, a jednym z głównych powodów czytania obcojęzycznej fantastyki w oryginale była chęć sprawdzenia, jak ,naprawdę” wygląda znany już tekst. Wszystkie te wyniki potwierdzają duże zaangażowanie w lekturę i gotowość, by na miarę umiejętności językowych sprawdzać i oceniać pracę tłumacza.

Duży procent respondentów, mając do wyboru dwóch niedoskonałych tłumaczy, wolałby przeczytać przekład sporządzony przez kogoś, kto jest osobiście czytelnikiem i miłośnikiem gatunku, co do kogo nie ma wątpliwości, że zna dany utwór jako fan, ale choć zna oba języki, nigdy dotąd profesjonalnie nie thumaczył, niż kogoś, kto jest profesjonalnym tłumaczem literatury pięknej, jego kompetencje językowe i literackie nie budzą wątpliwości, ale nie zna, osobiście nie czyta i nigdy nie tłumaczył fantastyki (59\% i 44\%, zależnie od grupy; w obu grupach hipotetyczny tłumacz-profesjonalista 
przegrał z tłumaczem-fanem, otrzymując odpowiednio 23\% i 36\% wszystkich głosów, pozostali respondenci nie mieli zdania). Wygląda więc na to, że wartości, jakie może zapewnić doświadczony tłumacz, są dla fanów mniej istotne niż potencjalne problemy, jakie może przynieść jego brak znajomości gatunku. Znów wydaje się, że kluczem do zrozumienia spojrzenia fanów może być, przynajmniej do pewnego stopnia ${ }^{4}$, kwestia spójności przekładu i jego tożsamości gatunkowej. Zrozumienie mechanizmów działania fikcyjnych światów, znajomość rozległych literackich i multimedialnych serii, umiejętność rozpoznawania nawiązań do innych tekstów gatunku - wszystko to wymaga uwagi i chęci przeszukiwania źródeł, których zdaniem respondentów może najwyraźniej zabraknąć komuś, kto jest „tylko” tłumaczem literackim.

Stanowisko fanów może przenikać do świadomości tłumaczy, ponieważ aż co piąty respondent zadeklarował, że zdarzało mu się zwracać do tłumaczy z uwagami na temat przekładu; nieco więcej niż jedna piąta kontaktowała się też z wydawcami lub polskimi dystrybutorami tekstów. Wielu fanów angażuje się w dyskusje o fantastyce, prowadzenie blogów, pisanie amatorskich kontynuacji i przeróbek istniejących tekstów (fanfiction), a nawet tworzenie amatorskich przekładów, mają więc gdzie i jak demonstrować swoje preferencje; równocześnie wielu tłumaczy fantastyki jest rozpoznawalnych w społeczności fanowskiej, której nierzadko są lub byli członkami, można więc zakładać, że przepływ informacji o oczekiwaniach fanów naprawdę istnieje. O ile tłumacze kształtowali niegdyś obraz gatunku wśród fanów, o tyle fani mogą teraz współkształtować kulturę przekładu, podobnie jak to było w mniejszych środowiskach klubowych.

Przenikanie się perspektywy fana i tłumacza, historii gatunku i nowych wyzwań, może zilustrować życiorys wybranego tłumacza. Michał Jakuszewski według bazy Fantasta.pl ma na koncie 122 przekłady książkowe i 123 przekłady opowiadań z gatunków science fiction, fantasy i horroru. Zaczynał jako fan; w roku 1981, a więc w okresie formacyjnym, wstąpił do łódzkiego klubu miłośników fantastyki Phoenix, gdzie zaproponowano mu

${ }^{4}$ Innym czynnikiem wpływającym na preferencje mogłaby być na przykład bezpośrednia znajomość z tłumaczami fantastyki wywodzącymi się ze społeczności fanów albo poczucie tożsamości grupowej wywołane uczestnictwem respondentów w tej społeczności. Badanie ankietowe nie potwierdziło jednak zależności między częstotliwością uczestnictwa w zlotach fanów (a więc typem aktywności tworzącej więzi grupowe w najbardziej oczywisty sposób) a przekonaniem respondentów o wyższości tłumacza-fana nad tłumaczem-fachowcem (Guttfeld, Jankowiak, Krawczyk 2013: 51-55). 
przekład „klubówek”. Po roku 1990 nowo powstałe wydawnictwa, zakładane przy udziale fanów, zwróciły się do niego, by wykorzystać przekłady klubowe i zaproponować dalszą pracę tłumacza, która w końcu przyćmiła pracę lekarza radiologa. W wywiadzie dla portalu Katedra krytycznie wyraża się o swoich wczesnych przekładach; momentem przełomowym, w którym odważył się na indywidualne, nietypowe podejście do przekładu, była, jak mówi, „Czarna Kompania Glena Cooka, w której chyba po raz pierwszy na polskim rynku fantastyki odważyłem się przetłumaczyć wszystkie imiona i nazwy"; wydany w 1993 roku przekład był na tle ówczesnych standardów dość znaczną adaptacją oryginału, również jeśli chodzi o użycie odmian języka potocznego. Ponieważ była to pierwsza część cyklu, prawdopodobnie zadecydowała o jego sukcesie i przysporzyła mu naśladowców nie tylko wśród innych tłumaczy, ale i polskich autorów. W 2002 roku Jakuszewski został poproszony o poprowadzenie dalej przekładu serii G.R.R. Martina Pieśń lodu i ognia, a następnie wsteczne poprawienie Gry o tron, przełożonej już przez Pawła Kruka pierwszej części cyklu (Jakuszewski 2006).

Przejęcie przekładu po innym tłumaczu i dalszy przekład wciąż nieukończonej serii wysunęły na pierwszy plan kwestie spójności terminologicznej i logiki świata przedstawionego, które wymagają przekładu raczej konserwatywnego i ostrożnego, skoro odsłaniany przezeń świat nie jest tłumaczowi w pełni znany. Cykl Martina wkrótce zaczął się przeradzać w większy świat literacki: pojawiły się historie rozgrywające się w czasach wcześniejszych, publikacje pseudohistoryczne i pseudokulturoznawcze poświęcone różnym jego aspektom, komiksy, gry fabularne, planszowe i komputerowe, a wszystkie one mogły wprowadzać nowe elementy leksykalne i konstrukcyjne przedstawionego świata. Żeby orientować się w coraz bardziej skomplikowanym uniwersum i teoriach fanów co do dalszego rozwoju akcji, oprócz kontaktów z autorem, Jakuszewski zaczął śledzić anglojęzyczne i polskojęzyczne fora fanowskie w internecie (Jakuszewski 2015). Przede wszystkim jednak ,markę” Martina zaczął tworzyć serial HBO, który stał się globalnym zjawiskiem kulturowym. Ponieważ seria powieści tłumaczona przez Jakuszewskiego nadal nie została ukończona, a serial, w którego tworzeniu Martin uczestniczy, wyprzedził już książkowy rozwój akcji i zawładnął wyobraźnią miłośników serii, w pewnym sensie przekład filmowy dyktuje teraz warunki tłumaczowi literackiemu (z którym nie był, przynajmniej do chwili udzielenia wywiadu, konsultowany) i trudno sobie wyobrazić, by przynajmniej niektóre kluczowe terminy czy frazy pojawiające się w przekładzie filmowym nie miały wpływu na przyszły 
przekład literacki. Tłumaczenie literackie stało się tylko jednym z okien na fikcyjny wszechświat.

Oczywiście nie sposób wyrokować o przemianach w ramach gatunku na przykładzie jednego tłumacza; sama baza Fantasta.pl, z pewnością niekompletna, w chwili pisania tego artykułu wylicza 2513 tłumaczy mających w dorobku utwory fantastyczne. Wydaje się jednak, że ten życiorys ilustruje, jaki wpływ na pozycję i zakres swobody tłumacza mogą mieć długofalowe trendy kulturowe: odłączanie się prozy gatunkowej od literatury głównego nurtu, a następnie jej włączanie w obręb kultury popularnej, gdzie rośnie udział mediów i tekstów o mniej autorskim charakterze, tworzonych zespołowo i z myślą o długofalowej eksploatacji i rozbudowie zestawu elementów, które wymagają kompleksowej i również długofalowej obsługi tłumaczeniowej. Jak zauważa Anthony Pym ${ }^{5}$, przy tego typu długoterminowych relacjach przekład nabiera cech typowych dla projektów lokalizacyjnych: w tłumaczeniu znaczenia nabierają stałość obsady, przewidywalność metody przekładu i ekwiwalencja na poziomie słownictwa, ogólną wizję tekstu kształtują zaś nie tyle tłumacze, ile menedżerowie (Pym 2010: 130).

\section{Bibliografia}

Braiter P. 1993. Tygrys szablastodzioby po raz pierwszy, „Fenix” 3 1993, http://fenix-antologia.pl/1992/03/01/tygrys-szablastodzioby-po-raz-pierwszy-tygrys-szablastodzioby/ (dostęp: 15.02.2018).

Dìaz Cintas J. 2003. Teoría y práctica de la subtitulación: Inglés-Español. Barcelona: Ariel.

Dìaz Cintas J., Remael A. 2007. Audiovisual Translation: Subtitling. Translation Practices Explained. Manchester: St. Jerome Publishing.

Even-Zohar I. 2005. Polysystem Theory (Revised), „Papers in Culture Research” 40-50.

Tel Aviv: Porter Chair of Semiotics, http://citeseerx.ist.psu.edu/viewdoc/summary? doi=10.1.1.112.4768\&rank=1 (dostęp: 15.02.2018).

${ }^{5}$ Badacz stwierdza, że przekład mniej autorskich tekstów, zwłaszcza jeśli stanowią serie i mają być szybko dostępne dla konsumentów, zaczyna przypominać lokalizację (rozumianą tu jako paradygmat stosujący się nie tylko do tekstów cyfrowych, ale też literackich). W tym modelu, z perspektywy tłumacza, ,zanika możliwość (...) całościowego spojrzenia. Tam, gdzie praca toczy się nad tekstem ciągle modyfikowanym i uaktualnianym, tłumacz zostaje zaangażowany w długoterminowy «program» lokalizacji, coś w rodzaju usługi zapewniającej regularny serwis techniczny pojazdu. W takich przypadkach ideałem jest przypisanie tych samych tłumaczy na stałe do danych tekstów czy klientów" (130, tłumaczenie moje). 
Fantasta.pl. 2018. Tlumacze, http://www.fantasta.p1/_fanDB/tlumacze.php (dostęp: 15.022018).

Głębicka E. 2017. Irena Lewandowska (biogram), w: Polscy pisarze i badacze literatury przełoти XXi XXI wieku, red. A. Szałagan, http://www.ppibl.ibl.waw.pl/mediawiki/ index.php?title=Irena_LEWANDOWSKA (dostęp: 15.02.2018).

Guttfeld D., Jankowiak D., Krawczyk S. 2013. Fantastyczni 2012 - badanie czytelnictwa fantastyki, http://gkf.org.pl/files/e-AF.pdf (dostęp: 15.02.2018).

Jakuszewski M. 2006. Wywiad z Michatem Jakuszewskim, rozm. T. Wronka, katedra. nast.pl/artykul/1530/Wywiad-z-Michalem-Jakuszewskim/ (dostęp: 15.02.2018).

- 2015. Westeros.pl: Wywiad z Michatem Jakuszewskim, polskim thumaczem cyklu ,Pieśń lodu i ognia", rozm. K. Igielski, http://westeros.pl/westeros-pl-wywiad-z-michalem-jakuszewskim-polskim-tlumaczem-cyklu-piesn-lodu-i-ognia/ (dostęp: 15.02.2018).

Lem S. 1976. List z dn. 19 grudnia 1976, http://archive.is/r83OP (dostęp: 15.02.2018).

Orliński W. 2007. Co to sa sepulki? Wszystko o Lemie, Kraków: Znak.

Pym A. 2010. Exploring Translation Theories, Abingdon: Routledge. 